K. Nesterenko ${ }^{1}$, S. Rahulin ${ }^{2}$, A. Sharabaiko

${ }^{1}$ Національний авіаційний університет, Київ, Україна

2 Льотна академія Національного авіаційного університету, Кропивницький, Україна

\title{
HUMAN FACTOR IN THE QUALITY IMPROVEMENT SYSTEM OF AIRCRAFT MAINTENANCE
}

\begin{abstract}
The subject matter of the article is the analyzes of the human factor in the quality improvement system of maintenance markers, which are aimed to evaluate the completeness of amount of work completed by the responsible party and technology of work performance as provided for by an engineering order, the goal is compare the results of the work of various operators and teams with established standards or against each other, for justification of measures aimed at quality improvement, evaluation of these measures effectiveness. On the basis of the purpose of the quality indicators and the methods for their determination, there are distinguished - initial quality evaluation, composite quality measures and overall quality level. Each type of maintenance quality evaluation has corresponding fields of application and calculation procedure. The methods used are semi-Markov processes with a finite set of states, a generalized structured method, the use of game theory, construction and analysis of cause and effect graphs, and situation assessment tree graph. Results. Taking into consideration the constant complication of aviation technique (AT), by means of new technologies introduction, new requirements are being put forward for the ground support personnel, and as the result, the price for aircraft failure has risen. That's why, the reduction of failures amount through the fault of maintenance personnel due to the psychological characteristics of their activities is among the priority tasks with regards to flight safety. This goes to prove that the influence of the human factor on the quality and effectiveness of aircraft maintenance has not been fully studied in world wide aeronautical science. Conclusions. In general, the problem of improving the quality of professional activities of maintenance operators is complex and research should concern the entire aspect of the factors affecting its performance.
\end{abstract}

Keywords: maintenance, maintenance personnel, aircraft maintenance facility, operator, quality indicators of maintenance efficiency.

\section{Methods of maintenance quality evaluation with consideration of maintenance personnel activity}

Maintenance is a package of works (operations) performed on AT during preparation for flights, after flights, during storage and transportation in order to maintain its serviceability and performance capability. Maintenance products are not any new products, but finished works anticipated by the production order. The quality of maintenance reflects the quality of labor of the maintenance personnel of the aircraft maintenance facility (AMF) [1].

The maintenance quality is ensured by the quality of maintenance personnel labor, the availability and quality of technological equipment, measuring tools and ground servicing, instruments and materials used when working at AT, and the perfect organization of the maintenance process. In the first place, the maintenance quality reflects the labor quality of maintenance personnel and AMF workers.

The quality of the operator's work is assessed by the degree of conformity with the received order of each completed work and the requirements of the operational documentation. Incomplete fulfillment of the order (scope of work), failure to reveal malfunctions during fault detection, performance of work with a faulty treatment is considered to be a defect in work. Failures and malfunctions detected during the flight also indicate an insufficiency of maintenance if they were a consequence of non-observance during maintenance.

A significant number of factors affect the quality of labor. The main groups of factors that have a decisive influence on the quality of maintenance personnel work are shown in Fig. 1 [2].

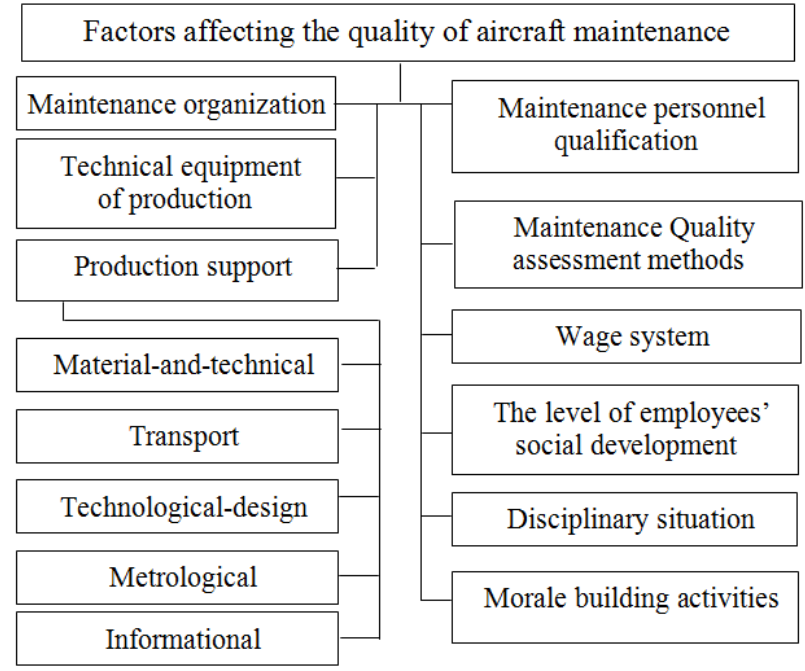

Fig. 1. Factors determining the quality of aircraft maintenance

Methods and models have been quite well established that describe the processes of technical operation, particularly, based on semi-Markov processes with a finite set of states, a generalized structured method, the use of game theory, construction and analysis of cause and effect graphs, and situation assessment tree graph. Existing methods and indicators aimed at evaluation of maintenance quality, with the consideration of the maintenance personnel activities, are directly related either to evaluation of an aircraft reliability in flight depending on the maintenance quality or evaluation of the aircraft maintenance quality, taking into account possible operators' errors. The mathematical expression connected with evaluation of the reliability of aircraft system in flight, depending on the maintenance quality, is as follows $[3,4]$ : 


$$
\begin{gathered}
P(t)_{\ni c}=\left(P_{H H}+\left(1-P_{H H}\right) P_{o o}\right) \times \\
\times\left[P_{c}(t)+\left(1-P_{c}(t)\right) P_{o H}\left(P_{y H}+\left(1-P_{y H}\right) P_{o o}\right)\right],
\end{gathered}
$$

where $p_{c}(t)$ - survival probability; $P_{\text {он }}$-probability of discovering trouble; $P_{y h^{-}}$troubleshooting probability; $P_{O 0^{-}}$detection probability of operator's error; $P_{H H^{-}}$ probability of failure non-recording.

In research [5-7], the investigation of aircraft reliability is reduced to considering the reliability of the aircraft, taking into account the activities of maintenance personnel.

Evaluation of the aircraft maintenance quality, taking into account the importance of the possible consequences of operator's errors, is discussed in the research. The evaluation formula is as follows:

$$
K_{j i}=1-\frac{1}{N_{j}} \sum_{k=1}^{m} C_{K} \cdot \Pi_{K},
$$

where $K_{j i}$ - quality indicator of " $j$ " maintenance according to " $j$ " maintenance form, meaning in its physical essence the "weighted" probability of errorfree aircraft maintenance by operators; $\Pi_{\kappa}$-the number of " $\mathrm{k}$ " errors made by the operator during the "i" maintenance according to " $\mathrm{j}$ " form; $K=1, \mathrm{~m}$ - is the number of errors having the same weight coefficient.

Weighting factors with regards to the importance of errors made by operators during aircraft maintenance are determined in advance for the entire list of possible errors by means of expert evaluation or by statistics of consequences.

Under the conditions, of a maintenance quality management system which is valid in companies' aircraft maintenance facility, a generalized quality factor $K_{o b}^{p}$ is used to evaluate the quality of operators' work. It is determined by summing the base coefficient, and the coefficients of its increase $\mathrm{K}_{\mathrm{ni}}$ and decrease $\mathrm{K}_{\mathrm{cn}}$ :

$$
K_{o b}^{p}=A+\sum_{i=1}^{n_{i}} n_{i} \cdot K_{n i}-\sum_{j=1}^{n_{j}} n_{j} \cdot K_{c H} ;
$$

where $A$ - basic ration $(A=100) ; n_{i}, n_{j}$ - incidents according to top performance and breakdowns.

For a department that does not have subordinate subdivisions (squads, shifts, sections), the generalized quality factor of work $K_{o б 3}$ is defined as the arithmetical average of the generalized quality factors of performers' work and engineers included in the department $[8,9]$ :

$$
K_{o b 3}=\frac{\sum K_{o b 1}+\sum K_{o b 2}}{m_{1}+m_{2}},
$$

where $m_{1}, m_{2}$ - number of performers and engineers in the department.

The generalized coefficient of the work quality of the department $K_{\circ 54}$, which includes structural subdivisions (workshop, aircraft maintenance facility overall), is calculated as the arithmetic mean value of the generalized coefficients of work quality of structural units which it includes:

$$
K_{o 64}=\sum K_{\text {обз }} / m_{3}
$$

where $m_{3}$ - the number of structural units in the department.

\section{The influence of a human factor on flight safety during aircraft maintenance}

The human factor (HM) is a uniquely complicated problem, as far as it focuses on the sociopolitical, moral - psychological, economic, biomedical, moral and legal aspects. The HM components are expressed in the specific conditions of the operator's interaction with technique, environment and represent the necessary basis for the successful implementation of their activities in the ergatic system "operator-aircraftenvironment". In any human activity, an operator's error has specific consequences. In aviation transport, an operator's error during aircraft maintenance in a number of situations leads to aircraft accidents [10].

Nowadays, operator's errors represent a potential threat to aviation safety in many respects. The commercial airline "Boeing" analyzed 220 documented accidents and revealed that the three most common causes of their occurrence are: nonobservance of established procedures by flight crews - $31.82 \%$; maintenance errors $-15.46 \%$; design defects $-15 \%$.

In the $60 \mathrm{~s}$, when this problem first began to considerably draw attention, the "contribution" of operator's errors to the set of causes of aviation accidents was estimated at about $20 \%$. In the 90 s, this index increased four times, and equaled $80 \%$. There are many reasons for such a steep increase, but the most essential of them are [11]:

$>$ over the past thirty years, the reliability of mechanical and electronic elements has increased substantially. Aircraft have become more automated and more complex. The aircraft of current generation such as the "Boeing 747-400" and "Airbus A340" have double and triple redundancy of flight control systems. This, possibly, reduces the load on the flight crew, but increases the requirements for technical specialists who carry out aircraft maintenance, many of whom received basic training in the field of mechanical rather than modern control systems based on the utilization of computer technology;

$>$ the increased complexity of the aviation system creates the opportunity for aviation accidents due to organizational shortcomings, errors made by operating personnel.

One of the reasons for several well-known accidents was the mistake of the operator during maintenance. The American Airlines DC-10 crash in Chicago in 1979 was as a result of a faulty treatment of engine replacement. In 1985, the Japan airlines "Boeing-747" crashed as a result of rapid decompression during the flight. Then, as the result of improper repair, the rear pressure bulkhead failed. And as a result that ensued excessive pressure increase in the tail section and the shock wave due to the explosive rupture of the spherical rear pressure bulkhead, the control system failed and the aircraft was destroyed, resulting in a multifatality accident. In April 1988, "Boeing 737" of Aloha airlines crashed as a result of the breakup of the upper fuselage structure. After all, the 
aircraft has been landed, with one person dead. This aviation accident was caused by a faulty treatment of maintenance technology. Distribution of all accidents for a variety of reasons during 1990-1999, on a worldwide basis, is shown in Fig. 2. There from, about $19.8 \%$ occurred on technical and technological issues.

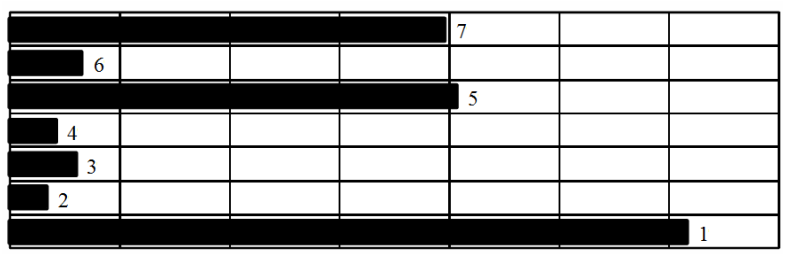

Fig. 2. Worldwide accidents for various reasons:

1 - Controlled Flight Into Terrain (CFIT); 2 -wind shear; 3 -Midair collision; 4 -icing; 5 -loss of control in the air; 6 fire / explosion on board; 7 -technical and technological issues

When analyzing 93 major global aircraft accidents that occurred between 1959 and 1983, it was found that in $12 \%$ of cases, shortcoming of maintenance was one of the factors that led to the accident.

As a result of this analysis, ICAO proposes the following list of basic causes of accidents shown as a \%. Accident cause:

- non-observance of standard proc. by a pilot, $93 \%$;

- insufficient cross-check by a co-pilot, $26 \%$;

- design defects, $13 \%$;

- maintenance shortcomings, $12 \%$;

- absence of approach guidance, $10 \%$;

- when PIC ignores crew members' messages, 10\%;

- air traffic control error / failure, $9 \%$;

- not correct actions of a crew, $9 \%$;

- insufficiency or inaccuracy, $8 \%$;

- runway hazards, 7\%;

- incorrect decision to land, $6 \%$;

- communication insufficiency, $6 \%$.

Not only flight safety, but also the regularity of flights and the economic performances of the operators' companies, due to non-production demurrage of the aircraft during their maintenance, control, replacement and repair of products, depend on the effectiveness of the maintenance specialists' operation.

Thereby, the increasing of operators' labor intensity every year and the complication of their activities during maintenance of new types of aircraft affects the quality of preparation for flight and the economic performances of aviation company.

This indicates the necessity of resolving the issue of the main directions with the help of which can be increased the reliability of operators' performance while ensuring aircraft flights.

\section{The main aspects of improving the quality and efficiency of aircraft maintenance}

One of the main stages of scientific and technological progress in civil aviation is the commissioning of new, more advanced types of aircraft and as the result the need to ensure appropriate maintenance, ensuring minimal demurrage and a high level of aircraft reliability. However, the steady increase of aviation technique complexity, the increasing labor intensity of the maintenance personnel with every year, the complication of their activities leads to the fact the problem of improving the quality and efficiency of aircraft maintenance is increasingly dominated by the operators' human factor

This is due to the fact that an increase in the aviation equipment complexity does not lead to a corresponding change through time of the physical and physiological abilities of the maintenance personnel who is serving the technique.

In such a way, one of the main aspects of quality improvement and efficiency of aircraft maintenance is the removal of nonconformity between aircraft and psycho physiological capabilities of people. This is possible only as a result of solving problems in the relationship of the system "operator-aircraftenvironment", which allows to increase professionally important quality of operations and their psycho physiological preparation.

Relationship aspects in the "operator-aircraftenvironment" system that affect the quality and effectiveness of maintenance include the level of automation and mechanization of maintenance processes, as well as the degree to which automated information systems are used. Among a large number of factors affecting labor productivity, mechanization and automation of production processes is of the utmost importance. This is one of the most important tasks solved by the aviation engineering service.

The concept of mechanization means development aimed at maintenance can be formulated as follows: to ensure aircraft maintenance with the lowest material and energy costs while reducing maintenance time and the number of employees.

The abovementioned concept can be implemented in the following way:

- modernization of existing mechanization means;

- transfer of all mechanization means to an electrically actuated ones;

- development and implementation of stationary systems for aircraft maintenance;

- add-ons to stationary systems with a device for automatic connecting of ground and airborne systems.

In maintenance purposes, the advanced directions can be reduced to the development of mobile and stationary means.

The development and implementation of new, improvement and modernization of existing means of mechanization and automation of aircraft maintenance processes is one of the main directions of reducing aircraft demurrage during maintenance, increasing labor productivity and the quality of aircraft maintenance. The improvement of the information system is closely connected with the built-in control systems, which, in combination with the on-board information systems assigned for maintenance, ensure the efficient utilization of aviation technology with minimal effort and resources. One of such integrated airborne system (OMS) was created for Boeing's aircraft. On the ground, the maintenance personnel may switch ON OMS to obtain the necessary information with regards to trouble 
shooting techniques or other data. OMS stores fault information during all stages of the flight. Information about all the faults that are currently available is reflected on the display. In British Airways, the special maintenance information system is widely used. It greatly facilitates the organization and control of the timely execution of maintenance works and the monitoring of the state of aviation equipment at each unit.

\section{Conclusions}

Maintenance information systems are becoming an integral part of the aircraft. On-board air monitoring systems transmit information regarding the state of aviation equipment so that, based on the data received, it is possible to determine in advance the necessary maintenance works and bringing the aircraft into a working condition.
Thereby, the utilization of automated systems in relation to the solution of maintenance tasks allows to obtain the following results:

- reduce flight delays;

- carry out more accurate calculations of the spare parts necessity and the composition of the work shift;

- reduce the time which aircraft spends during maintenance;

- use technicians of lower qualifications;

- control the technological processes of AT maintenance.

Taking all things together, the problem of improving the quality of maintenance operators' professional activities is complex and research should relate to the entire aspect of the factors affecting its performance.

\section{REFERENCES}

1. [The improving recommendation of the quality management system for aviation equipment maintenance in aircraft maintenance facility of civil aviation. - Moscow: AirTransport, 1986. - 48 p.(in Russian)

2. Textbook for universities / Smirnova N.N., Vladimirov N.I., ChernenkoZ h.S. / Edited by Smirnova N.N. - Moscow: Transport, 1990. - 423 p. (in Russian)

3. Quality management of aircraft products maintenance: VisnykKIU of CA \#2. Burlokov V.I., Yasser Canaan, Jihad Mansour Kiev, 1999. - p 204 - 212. (in Russian)

4. Svyrydov, A., Kuchuk, H., Tsiapa, O. (2018), "Improving efficienty of image recognition process: Approach and case study", Proceedings of 2018 IEEE 9th International Conference on Dependable Systems, Services and Technologies, DESSERT 2018, pp. 593-597, DOI: http://dx.doi.org/10.1109/DESSERT.2018.8409201

5. Reliability and efficiency in technology: Reference textbook: - Moscow: Mashinostroyeniye, 1986. vol. 1. Methodology. Organization. Terminology / Avduyevskiy V.S. and other. Edited by Rembezy A.I. 1986.- 223 p. (in Russian)

6. Kovalenko, A. and Kuchuk H. (2018), "Methods for synthesis of informational and technical structures of critical application object's control system", Advanced Information Systems, Vol. 2, No. 1, pp. 22-27, DOI: https://doi.org/10.20998/2522-9052.2018.1.04

7. Kuchuk G., Kovalenko A., Komari I.E., Svyrydov A., Kharchenko V. Improving big data centers energy efficiency: Traffic based model and method. Studies in Systems, Decision and Control, vol 171. Kharchenko, V., Kondratenko, Y., Kacprzyk, J. (Eds.). Springer Nature Switzerland AG, 2019. Pp. 161-183. DOI: http://doi.org/10.1007/978-3-030-00253-4 8

8. Evaluation of the aircraft maintenance quality according to the results of its certification. Improvement of the maintenance production processes and repair of aviation technique // Collection of research papers. Popov V.G. and Vashchenko G.V. \#274. 1988. p. 66 - 69 (in Russian)

9. Dhivakar B., Saravanan S.V. Statistical Score Calculation of Information Retrieval Systems using Data Fusion Technique". Computer Science and Engineering. 2012. Vol. 2, Issue 5. pp.43-45. doi: http://doi.org/10.5923/j.computer.20120205.01

10. Current status and development prospects of ergonomics in civil aviation. Aviation Ergonomics // Interuniversity collection of scientific papers. Edition \# 4.Bugaev B.P. - Kiev, 1978. -99 p.(in Russian)

11. The role of the human factor in aircraft maintenance/ Cir 253-AN/151/ICAO/ - 1995 (in Russian)

Received (Надійшла) 11.11.2019

Accepted for publication (Прийнята до друку) 22.01.2020

\section{Людський фактор у системі підвищення якості технічного обслуговування повітряних суден}

\section{К. С. Несторенко, С. В. Рагулін, О. М. Шарабайко}

Анотація. Предметом вивчення в статті є людський фактор в системі підвищення показників якості технічного обслуговування, які призначені для оцінки повноти дотримання виконавцями обсягу і технології виконання робіт, передбачених завданнями на обслуговування. Метою $\epsilon$ порівняння результатів роботи різних операторів і колективів 3 встановленими нормативами або між собою, для обгрунтування заходів, спрямованих на підвищення якості, для оцінки ефективності цих заходів. Залежно від призначення показників якості та методики їх визначення розрізняють початкові оцінки якості, узагальнені показники якості і загальний рівень якості. Кожен вид оцінок якості технічного обслуговування має відповідні області застосування і порядок розрахунку. Методи: напівмарковських процесів з кінцевим безліччю станів; узагальненого структурного методу; використання теорії ігор; побудови і аналізу причинно-наслідкових графів, дерев оцінки ситуацій. Результат. В зв'язку з неухильним ускладненням АТ, впровадженням нових технологій висуваються все нові вимоги до персоналу наземних служб, відбувається зростання ціни за відмову авіатехніки. Тому зниження частки відмов 3 вини обслуговуючого персоналу, обумовлених психологічними особливостями його діяльності, відноситься до числа пріоритетних завдань фахівців з безпеки польотів. Це свідчить про те, що вплив людського фактора на якість $\mathrm{i}$ ефективність технічного обслуговування повітряних суден недостатньо повно вивчено в світовій авіаційній науці. Висновки: в цілому проблема підвищення якості професійної діяльності операторів 3 технічного обслуговування $€$ комплексною і дослідження повинні стосуватися всього аспекту факторів, що впливають на його показники.

Ключові слова: технічне обслуговування, обслуговуючий персонал, авіаційно-технічна база, оператор, показники якості ефективність технічного обслуговування. 